\title{
Depository Library Council: An Overview
}

\author{
Susan E. Tulis
}

What do claims, wrinkled shipping lists, minimal level cataloging, split item numbers, rain checks, and inverted List of Classes all have in common? These are just some of the many issues members of the Depository Library Council to the Public Printer have addressed during the last seventeen years.

The passage of the Depository Library Act of 1962 resulted in changes to the law that governs the distribution of federal government publications to designated depository libraries. These changes to the law caused the Public Printer of the United States, an individual nominated by the President to manage the Government Printing Office, to seek advice and recommendations from the library community on the implementation of the new depository library program. During its consideration of H. R. 8141, which became this Depository Library Act of 1962 (P. L. 87-579), the Senate Committee on Rules and Administration recommended that just such an advisory committee be formed. Seven librarians were asked to serve as members of this first advisory committee which was established in 1972 and held its first meeting in 1973. This initial advisory committee served as a model for the present Depository Library Council (DLC), a fifteen member advisory board to the Public Printer.

One of the first acts of Council was to draft a Charter and Bylaws, which were adopted in January 1975. The Bylaws were amended in October 1977 and April 1986. Further amendments are currently under discussion.

The purpose of the Depository Library Council as stated in the Charter is "to provide advice on matters dealing with the Depository Library Program as provided in title 44, U.S.C." It also specifies that this advice "will include but not be limited to classification, distribution, cataloging, indexing, storage, availability, and utilization of depository material and general administration of the Depository Library Program."

Susan E. Tulis is Documents Librarian at the University of Virginia's Arthur J. Morris Law Library in Charlottesville.
Appointments to Council are made by the Public Printer who seeks recommendations from librarians at large, the American Library Association, the American Association of Law Libraries, the Special Libraries Association, and from Council itself. The Bylaws specify that "at least five of the members of the Council shall be persons who work full time with government documents in a depository library." There has also been an attempt to achieve a geographical and a type-oflibrary balance.

The fifteen members of Council serve staggered three-year terms. The officers of the Council consist of a Chair, Chair-elect, and Secretary. The Chair-elect is nominated by the Council and confirmed by the Public Printer. The Secretary is appointed by the Chair.

The current Bylaws specify that "the Council shall meet twice a year, in the spring and in the fall, at times and locations designated by the Public Printer." The first meeting of the original fourteen members was held in Washington, DC on February 2, 1973. This meeting, and the next three, were one-day sessions scheduled at the time of ALA meetings-Las Vegas, NV, June 28, 1973; Chicago, IL, January 25, 1974; and New York, NY, July 6, 1974. Subsequent meetings were two-day sessions and then two and one-half day sessions held in October and in the spring.

Much of Council's work has been done through the use of committees the names of which have changed over the years. During the last six years, Council has operated with a Committee of the Whole because so many of the issues affected more than one committee. The Micrographics Committee was an ad hoc committee that was dissolved in April 1979 because it was felt that it had met its charges and that its tasks had been accomplished. Its duties were transferred to other committees in existence at the time. Some of the other committees that have existed are GPO Operations, Depository Libraries, National System, Bibliographic Control, and Depository Systems.

Council's modus operandi is to hold semiannual meetings to discuss the current issues, 
listen to various presentations and comments from depository librarians, and then to write its recommendations to the Public Printer for his consideration and response. Depending upon the issues, research may be done and reports written before or after the meetings. Occasionally, the Public Printer has requested advice from his Council between meetings. This is difficult for everyone. When asked for advice between meetings, Council finds it difficult to get a sense of the majority opinion of the depository libraries. Council has always asked depositories to submit their concerns to any member before or during meetings.

...dwindling resources and
rapid technological change
have increased the pressure
to organize and deliver
greater quantities of infor-
mation more efficiently.

\section{Issues, Concerns, Accomplishments}

Council has dealt with many issues and concerns over the past seventeen years, some taking longer than others, some evolving into other issues, and some still being dealt with. They range from the "nitty-gritty" to larger, more global issues. The areas of interest and/or concern have covered such things as the Monthly Catalog, the inspection program, micropublishing, acquisition and distribution of depository documents, automation projects at GPO, standards and guidelines, and communications. As part of its work, Council has produced many useful guides and manuals, such as the "Federal Depository Library Manual." 2 Council's role has not become simpler over the years. Instead, dwindling resources and rapid technological change have increased the pressure to organize and deliver greater quantities of information more efficiently.

Besides the writing of the Charter and Bylaws, the early Council meetings were dominated by concern about the performance of depository libraries. A uniform level of performance by depositories was needed for the system to run efficiently. The law provides for inspection, but inspections could not be conducted without standards and guidelines. So Council wrote a draft, solicited and incorporated comments, and produced the "Guidelines for the Depository Library System." 3
The entire inspection process has been of concern to Council. In 1978 Council developed a comprehensive inspection form which follows the general outline of the "Guidelines." As a result of the new form and suggestions made by Council, more objective evaluations were made of depositories. One recommendation was to conduct the inspections in a spirit of helpfulness, rather than fault-finding, by determining the problems encountered in the effort to implement the "Guidelines." Another suggestion was to hire more inspectors, thereby shortening the time between inspections. (It was suggested early on that inspections be done at least every two years. Even with five inspectors, it is impossible to inspect the more than 1,400 depository libraries this often.)

Bibliographic control is a vital part of making government information accessible to the public. The major bibliographic tool produced by GPO is the Monthly Catalog of United States Government Publications. Council has been instrumental in changes made to this tool and other Monthly Catalog products. The biggest change was automating the Monthly Catalog. The July 1976 issue was the first one with a new format, using AACR and Library of Congress Subject Headings. GPO also joined OCLC during this time. Other improvements include the KWIC (Key Word in Context) Index, the Serials Supplement and the semiannual cumulated indexes. The time lag between the cataloging of documents and their appearance in the Monthly Catalog was shortened. The Monthly Catalog is now issued in a more timely fashion, as are the annual indexes. We have also seen the inclusion of SuDocs numbers in some of the indexes along with the entry number for the full bibliographic record. The more recent issues related to the Monthly Catalog have centered on the corresponding computer tapes. With more and more libraries creating online catalogs, there was great concern about updating the tapes. The problems with the tapes range from incorrect and inconsistent use of fields within data entries to massive duplication of serial records.

Another area of bibliographic control is that of "non-GPO" publications being listed in the Monthly Catalog and also distributed to depositories. ("Non-GPO" means publications issued by field offices, military bases, overseas plants, and other Federal agencies and printed on their own equipment or elsewhere.) It is important not only to be able to identify that a government publication exists, but also to be able to locate it in a depository library. 
The issue of "fugitive documents" has been a topic of discussion for many years. Another issue not yet resolved is how to have GPO achieve more complete coverage within item numbers. Acting on a Council recommendation, GPO did create an Acquisitions Section which helped with some of the fugitive documents problems. This issue will undoubtedly carry over into future Council agendas.

Council has been very involved with GPO micropublishing-from the inception of the whole program to the current problems with the microfiche contracts. Council encouraged GPO to proceed with the microform project as planned and to expand the program to include non-GPO publications which were unavailable for distribution in hard copy. Council recommended titles for the initial conversion to microfiche, but the selection process was made easier by GPO's decision to allow depositories to select either hardcopy or microfiche. Later, on the other hand, Council was asked to give titles or categories of publications that could be converted for microfiche distribution only, due to budget problems. These were not fun or easy decisions, but they are ones we have all had to live with. Council also dealt with the issue of replacement fiche. Now it appears that we have moved on to another technology, CDROM. This has opened up new areas of concern such as claim copies, replacement copies, storage of the master, and adequate retrieval software.

Automation has been an ongoing concern. There is no one integrated system within GPO. The Sales section has one online system, and Library Programs Service has another. Depository librarians keep hearing about the Acquisition, Classification, and Shipment Information System (ACSIS), the system that will solve many of our problems, but it seems to be further and further down the road.

Other accomplishments of Council include developing the decal that all depository libraries are required to display.

Through the encouragement of Council, Public Documents Highlights was started as a medium for the exchange of information between GPO and depository libraries. Administrative Notes now serves that purpose. Council suggested that Regional Depository meetings be supported by GPO. The first one was held July 13, 1974, and others have been held intermittently since then. Studies have been recommended, such as the one undertaken by Washington State Library to deter- mine the cost per regional depository library for services to selective depositories, and the McClureHernon study to determine the use of depository libraries. ${ }^{4}$

Two librarians from North Carolina have served on Depository Library Council. Clifton Brock, University of North Carolina at Chapel Hill, served during 1973-76. Ridley Kessler, also from UNC-Chapel Hill, is serving from 1987-90 and is the current Chairperson of DLC.

\section{The issue of "fugitive documents" has been a topic of discussion for many years.}

Obviously, this article highlights only some of the many issues and accomplishments over the years. Whatever the issue, it always poses a challenge for the Council members. T. F. McCormick, Public Printer 1973-1977, summed it up best in his foreword to the First Report to the Public Printer 1972-1976. He wrote that "Council members have given generously of their time and thought in the critical examination of the philosophical and operational basis of the depository library program. Their recommendations have moved from the tentative and conjectural to specific guidelines designed to give the program greater scope and effectiveness." Mr. McCormick's comments about the Council members during its first four years continue to be true about Council members who have served since then.

\section{References}

1. The Charter and Bylaws can be found in Appendix B of Depository Library Council to the Public Printer (U.S.), Fourth Report to the Public Printer 1978-1979 (Washington, DC: U.S. Government Printing Office, September 30,1979 ). This is the Charter as adopted October 29, 1974 and the Bylaws as amended October 18, 1977. Note: Article VII, Section 2 "Annual Reports" was deleted from the Bylaws by vote of the Depository Library Council, with the concurrence of the Public Printer, in April 1986. 2. The "Federal Depository Library Manual" created by the Depository Library Systems Committee of Depository Library Council in 1985, is found as Part III of the Instructions to Depository Libraries (Washington, DC: U.S. Government Printing Office, revised 1988).

3. The "Guidelines For The Depository Library System," revised 1987, is found as Part II of the Instructions to Depository Libraries (Washington, DC: U.S. Government Printing Office, revised 1988).

4. Charles R. McClure and Peter Hernon, Users of Academic and Public GPO Depository Libraries (Washington, DC: U.S. Government Printing Office, 1989). 